Journal of Southeast Asian

\title{
Racism, Schooling, and the Streets: A Critical Analysis of Vietnamese American Youth Gang Formation in Southern California
}

Kevin D. Lam

Drake University, kevinlam12@gmail.com

Follow this and additional works at: https://docs.lib.purdue.edu/jsaaea

\section{Recommended Citation}

Lam, Kevin D. (2012) "Racism, Schooling, and the Streets: A Critical Analysis of Vietnamese American Youth Gang Formation in Southern California," Journal of Southeast Asian American Education and Advancement: Vol. 7 : Iss. 1, Article 1.

DOI: $10.7771 / 2153-8999.1043$

Available at: https://docs.lib.purdue.edu/jsaaea/vol7/iss1/1

This document has been made available through Purdue e-Pubs, a service of the Purdue University Libraries. Please contact epubs@purdue.edu for additional information.

This is an Open Access journal. This means that it uses a funding model that does not charge readers or their institutions for access. Readers may freely read, download, copy, distribute, print, search, or link to the full texts of articles. This journal is covered under the CC BY-NC-ND license. 


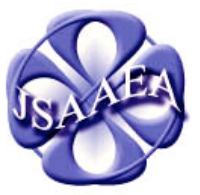

Volume 7 (2012)
Journal of Southeast Asian American Education \& Advancement

WWw.JSAAEA.org
A peer-reviewed

\title{
Racism, Schooling, and the Streets: A Critical Analysis of Vietnamese American Youth Gang Formation in Southern California
}

\author{
Kevin D. Lam \\ Drake University
}

\begin{abstract}
This paper is an analysis of the relationship between educational experiences, street life, and gang formation for Vietnamese American youth gang members in Southern California. I use critical narrative methodology to center the life and experiences of a Los Angeles area gang member. His narrative substantiates how racism in schools and on the streets works together to impact and inform gang formation. Schools were sites of inter-ethnic conflict and racialized tension, and streets were spaces for contentious interactions with the police. In addition, I place the Vietnamese American youth gang phenomenon in larger historical and political contexts such as California's anti-youth legislation, representations of Asian American youth, and U.S. geo-politics and imperialism-factors that have serious material and ideological implications and consequences.
\end{abstract}

KEY WORDS: youth gangs, Vietnamese Americans, racism, critical narrative methodology, inter-ethnic conflict, criminalization

\section{Introduction}

Compared to other racialized youth groups, very little is known about Asian American youth and even less about those who are gang members. This is by no means surprising, given that Asian Americans are not necessarily perceived as worthy theoretical and political subjects of inquiry, due to where they are located in the U.S. racialized hierarchy. To put it more clearly, Asian Americans are not considered "marginalized enough" in their marginal status as a minority population in the U.S. to warrant critical examination. In our attempts to create a truly progressive politics of difference in these times, it is fundamental that we rethink how marginalized populations are racialized and represented, in particular, urban youth of color. Although much research is needed, the available data does suggest that certain Asian American ethnic youth groups, including Vietnamese, face serious issues with poverty, school dropouts, and juvenile delinquency (Umemoto \& Ong, 2006).

\section{@)}

SOBRERIGHISRESERVED Readers are free to copy, display, and distribute this article, as long as the work is attributed to the author(s) and the Journal of Southeast Asian American Education \& Advancement, it is distributed for noncommercial purposes only, and no alteration or transformation is made in the work. More details of this Creative Commons license are available at http://creativecommons.org/licenses/by-nc-nd/3.0/. All other uses must be approved by the author(s) or JSAAEA. 
Not coincidentally, the emergence of Vietnamese American "street" gangs coincided with California's increasing racialization of youth and, in particular, gang members of all hues. Such criminalization is usually associated with Black and Chicano/Latino youth; as a result, discussions of youth of color impacted by the juvenile justice system often overlook Asian American and Pacific Islander youth. However, the reality is that arrest rates for Asian and Pacific Islander youth have increased dramatically while the national arrest rates for black and white youth have declined in the last 20 years (Kwon, 2006, p. 221; Le, 2002). Since Asian American youth (including Vietnamese Americans) are racialized as model minorities and presumably non-violent, they are not necessarily given the same kind of legitimacy by their peers, policy makers, scholars, and educators when discussing gang violence and historical/personal struggles. In California's urban centers, however, they are racialized as both model minority and gang-banger because of the substantial number of Asian American youth gangs.

In this paper, I examine the ways in which Vietnamese American youth gangs members in Southern California experience schooling - in particular, inter-ethnic conflict with other youth of color. I argue that schooling needs to be understood in relation to questions of racism, migration, and class. These factors are interconnected, and they speak to why it is important to frame the subject matter within larger social, political, and economic contexts. I describe classroom experiences but also discuss the relationship between schooling and the communities in which Vietnamese American youth gang members attend school. I want to understand the connection between schools and "the streets." More specifically, I believe it is necessary to understand these two entities dialectically. I explore (a) how Vietnamese American youth gang members experience racialized schooling, (b) the dialectical relationship between schooling and "the streets," and (c) the significance of racism for Vietnamese American youth gang members.

\section{Literature Review}

\section{Representation of Asian American Youth}

Although this paper is on Vietnamese American youth, it is necessary to discuss the representation of Asian American youth because of the long history of racialization of Asian American subjects as a whole. The rhetoric of Asian Americans as a model minority and Vietnamese as the good refugee has been harmful in its distortion of the complex issues that take place in immigrant and racialized communities. The simplistic representation of Asian American youth as "whiz kids" (Osajima, 2000); their "over-representation" in higher education (Hune, 2002); and the ability of Asian Americans to overcome any obstacle to excel and flourish, reinforced the idea of America as the "land of opportunity" and a "refuge for democracy" (Espiritu, 2005, 2006). Such one-dimensional distortions have definitely cast a shadow over those who have not done as well, including Asian American youth who drop out of school, get caught up in the juvenile system, and struggle with adolescent life (Umemoto \& Ong, 2006, p. v). Indeed, these are some of the central issues in this paper. This alone points to a longstanding need for research and analysis on Vietnamese Americans and Asian Americans that substantively examines the problems, concerns, and hardships faced by this population, especially its youth. 


\section{Asian American Youth Gangs}

At the turn of the 21 st century, the estimated number of youth gangs nationally was over 30,000 , and the number of gang members was over 800,000. The Los Angeles area, being the "gang capital of the U.S.," tops the list with close to 8,000 gangs and 200,000 gang members (Vigil, 2002). Asian American youth gangs account for 3 to 6 percent of the entire gang population, as reported by the National Youth Gang Center (Vigil, 2002). Although these statistics give us a sense of gang formation numerically, it is oftentimes difficult to label given the various degree of gang involvement. With that said, Asian American youth gangs make up a relatively small percentage of all youth gangs nationally. However, it is estimated that there are 20,000 Asian American gang members in Los Angeles County alone (Asian Gangs in Los Angeles County, 2012). The ethnic breakdown for Vietnamese is unknown given that some youth groups tend to include other Southeast Asian Americans. Although many share similar class backgrounds and immigration histories, I make the distinction between Vietnamese/Southeast Asian youth gangs and Chinese/Taiwanese and some Filipino American youth gangs. The latter two migrated under very different contexts, as a number of these youth (certainly not all) settled in more "suburban" middle-class areas in Southern California.

\section{Vietnamese American Youth Gangs: A Brief History}

It is important to note that the emergence of Vietnamese American youth gangs coincides with the "second wave" that came from Vietnam in the late 1970s and early 1980s, which exacerbated the "boat people" crisis in their escape from Vietnam. A significant number of "boat people" (over 50 percent) were young children or teenagers, and some came without parents or other family members (Chan, 1994; Vigil, 2002). Unlike "first-wave" families that arrived mostly intact, a significant number of "second-wave" youth came on their own because parents did not have the resources to pay for their own escape. Oftentimes, these youth would make the journey with a relative or a family friend. The "second wave" refugees were also comprised of more rural and working-class Vietnamese and ethnic-Chinese, which made up 70 percent of these refugees (Chan, 1994; Takaki, 1989). As a group, they were less educated and familiar with Western ideology and values, compared to the "first wave" that migrated immediately after the Fall of Saigon in 1975.

The first generation of Vietnamese youth who became involved in gangs in the early and mid-1980s are now dead, in prison, or grew out of "the game." Building on the works of James Diego Vigil and his associates $(1998,2002,2006)$, I have found a prominent phenomenon of second-generation Vietnamese American youth gangs that are more street-socialized than their predecessors. By any account, they are products of U.S. youth gang culture that emerged in major cities across the U.S. Historically, Black and Chicano/Mexican American gang activity has been demarcated by streets and blocks. Yet Vietnamese and Asian American gangs do not adhere to traditional conceptions of the "street," given the fact that Vietnamese in particular and Asian Americans in general have very different residential and settlement patterns when compared with other racialized populations. Vietnamese American youth gangs are not spatially bound. If anything, Vietnamese American youth gangs complicate our commonsense notions of "urban" and "street" gangs. They do not necessarily claim turf or territory, as it is understood (Gonzales, 2004). As a result, their businesses, both legitimate and illegitimate, are not necessarily governed by rules of the "streets." 
In the context of schooling, the early arrivals from Vietnam in the early 1980s faced the negative effects of a fairly recent and highly divisive war. They were reminders of the enemy, the "yellow peril" who moved in next door, both literally and metaphorically. Invariably, they were often targets of physical and verbal attacks from other students due to their comparatively smaller stature, different physical characteristics, refugee status, limited English language proficiency, and distinct hairstyle and dress (Vigil \& Yun, 1998).

Many of these youth grew up in poor and working-class neighborhoods with other Asians and Latinos, in areas where there has been a long history of gangs. Inevitably, they came into conflict because they had to share the same spaces and go to the same schools. Some Vietnamese American youth got picked on when they were younger by more established Chicano gangs in the area. As a way to protect themselves, establish their own sense of identity, and find ways to deal with their family's material conditions, these youth formed their own gangs.

Gang formation also has diasporic and national effects. Vietnamese American youth gangs become connected to the larger patterns of people moving out to other areas of California and to other parts of the U.S. Given the deportation of many youth gang members to their countries of origin since the mid- to late 1990s, a transnational element is also taking place. We see this take form in countries like El Salvador and Cambodia (Chow, 2005; Guerra Vasquez, 2005). Vietnamese American gang members are very aware that they might be next in line to get deported, as the U.S. and Vietnam continue to normalize diplomatic relations.

\section{Theoretical Framework}

This paper seeks to understand the dialectical relationship between large-scale forces like immigration, war, geo-politics, and empire and the particularities of youth gang formation (Nayak, 2003, p. 6). For this reason, I examine the Vietnamese American youth gang phenomenon in relation to experiences of gang members in the schools and "the streets." These two entities inform one another and by no means can be separated.

My theoretical framework is also informed by critical educational theorist Paulo Freire's (1970, 1993) notion of humanization:

While both humanization and dehumanization are real alternatives, only the first is the people's vocation. This vocation is constantly negated, yet it is affirmed by that very negation. It is thwarted by injustice, exploitation, oppression, and the violence of the oppressors; it is affirmed by the yearning of the oppressed for freedom and justice, and by their struggle to recover their lost humanity. (p. 26)

Freire succinctly describes the struggles that a number of Vietnamese American gang members are going through. They struggle to fully live because of the conditions surrounding them, including both real and symbolic violence, racism, and marginalization. The choices and decisions they make (arguably, perhaps they do not have a choice) cost them dearly, as a number of them are locked up, dead, or just trying to survive. This article is fundamentally a humanizing project that desires to give voice to the most marginalized in society. It seeks to give redeeming value to those that are marked most deviant in society and "the wretched of the earth," to borrow from Fanon (1963). 


\section{Critical Narrative Methodology}

I used critical narrative methodology for the research. D. Soyini Madison (2005) outlines three key main points that were very helpful for my interviews with Vietnamese American youth gang members. First, Madison discusses the importance of positionality as researchers. She suggests that it is fundamental to "acknowledge our own power, privilege, and biases just as we denounce the power structure that surround our subjects" (p. 14). I was clear with my subjects about the research goals and intentions. This is articulated through my research questions, methodology, and theoretical frameworks that drive this work. They agreed to do the interviews because of the level of trust and respect placed on the intermediary. In this manner, it was also extended to me because of my close relationship with these intermediaries. At the time of the research, I was positioned both as a "graduate student/researcher" and perhaps more significantly, as someone "from the neighborhood" who could and would respect their humanity.

Second, Madison (2005) speaks of the need to engage in a dialogical manner with your research subjects: "Dialogue emphasizes the living communion of a felt-sensing, embodied interplay and engagement between human beings... It keeps the meanings between and the conversations with the researcher and the Other open and ongoing" (p. 14). There was a sense of dialogical engagement with both myself and the subjects. As much as they shared with me their life stories, I was also willing to engage them in mine-as open and honest as I possibly could. I believe that they were as open and honest as they were because we were in dialogue with one another. It is clear to me that these subjects, through their narratives, want to be in dialogue with the rest of the world. They, as Vietnamese American subjects, want to be heard and to be able to share their pain, frustration, joy, sorrow, and happiness. They expressed that no one is really hearing them, and to a greater extent, not recognizing their history and humanity. More succinctly, one interviewee expressed that "no one is looking into our shit" and that folks "don't understand the roots of it." In many ways, I am trying to do both.

Third, Madison (2005) stresses the importance of the theory/method nexus. Hence, critical ethnography becomes the "doing" of critical theory: "Theory, when used as a mode of interpretation, is a method, yet it can be distinguished from method when a set of concrete actions grounded by a specific scene is required to complete a task. We rely on theory ... to interpret or illuminate a social action" (p. 15). In looking at the narratives and other sources, I am constantly engaged in theorizing Vietnamese American youth gangs. Much theorization, in concrete ways, is done through the grounding of the research, designing interview questions, developing themes, and coding the data (p. 15). For me, there has to be an alliance with theory and practice (method), as each drives the other.

\section{Research Design}

The larger project involved three Vietnamese American gang members in Southern California in November and December 2007. This paper presents a critical narrative from one interview, PDog. The interview was set up through an intermediary that both the researcher and interviewee trusted. To be sure, it really helped that I knew the contexts extremely well-as I attended similar schools and grew up in the community.

The in-depth interview with P-Dog was open-ended and lasted more than two hours. Before the interview began, I explained the purposes of the research and why he was asked to participate. I made clear that criminal activity is not the focus of the research. Rather, I was 
interested in hearing his story. During the interview, I used a digital recorder. He consented to be audio-recorded. It was made explicit to P-Dog that he was given all rights to turn off the audiorecorder at any given moment, ask questions or request clarification, or to retract certain information once it was recorded. I decided not take notes because I felt that it was important for me to engage him in dialogue. He was a bit apprehensive at the beginning. But once he felt comfortable, he was more than willing to share his experiences. I spent time writing out notes after the interview as well as my interpretations.

Before I proceed further, I also want to clarify the notion of "youth." Nayak (2003) problematizes the commonsense notion of youth:

Terms such as "youth" and "young people" are used for their economical ease. These terms have been subject to critique and should not be seen as biological states (e.g. "the pubescent teen") or psychological phases (e.g. "adolescence") in an individual's development. Instead, "youth" is treated here as a social and mutable category that continues to have different meanings in different times and places. (p. 3)

I am not using youth as a biological state, but rather analyzing youth gang formation - situated in very particular social and historical contexts. A critical narrative methodology is best used here because it allows the subjects to speak, substantively, on their own terms. They are able to bring much passion and humanity to their stories. P-Dog was 30 years old at the time of the interview. He got involved as a 13 year old and continues to be immersed in gang life. Below is a critical narrative from P-Dog.

\section{Critical Narrative: P-Dog}

P-Dog was born in Vietnam in 1977 and came to the U.S. as a three year old in 1980. His family migrated by boat from Vietnam across the South China Sea to a refugee camp in Hong Kong before resettling in Seattle, Washington. His father's siblings also resettled in Seattle. After spending a couple of years in the U.S. Northwest, P-Dog's father first made the drive down Interstate-5 to Southern California. P-Dog and his mother came shortly after. Although they did not have relatives in California, his parents had some friends from their hometown who settled in the "Golden State," around the same time they moved to Seattle. P-Dog and his parents moved to Lincoln Heights, a predominantly Latino and Asian American working-class section in Los Angeles and eventually to the diverse San Gabriel Valley. His mother is ethnic Vietnamese and father ethnic-Chinese from Vietnam.

P-Dog is a second-generation gang member. He is a member of the Asian Boyz. His father was an original member of Viet Ching, an ethnic-Chinese youth gang whose members were from Vietnam. They were part of the first wave of Southeast Asian youth gangs in Southern California in the late 1970s and early 1980s. As P-Dog's father and his homeboys were involved in the early 1980s as young adults, P-Dog and his homeboys were "putting in work" (by ways of committing violent offenses and getting involved in other illegal activities) in the early 1990s as teenagers. P-Dog states, "So what escalated is - what the story is - [my father's generation] brought the [Vietnamese-Chinese gangs] down here [to Southern California from Vietnam]." PDog parallels his refugee experience with that of fictional character Tony Montana, the notorious Cuban gangster from the movie Scarface: "I am from the refugees, man. I am from the camps. Same thing you see [with] Tony Montana in the Cuban camps ... when he got sponsored to the 
U.S. Same thing with us. [Montana] came as a dishwasher. My dad came here chopping meat [as a butcher]." His mother has worked in the nail salon business since the early 1980s. They got off welfare five years ago and Section 8 (federal assisted housing) two years ago.

In the early 1990s, P-Dog's Asian Boyz clique was the first generation of Asian gang members in the area to break away from tradition with their dress, style, and gang protocol. They were young and trying to build a "rep" [reputation]. For P-Dog, choosing to wear Dickies [clothing brand], Nike Cortez, and shaving off their heads was as much stylistic as it was a lifestyle:

A lot of people these days ... they think it's a style. But basically, it's not a style, it's a way of life. A lot of kids [are] wearing Cortez, Dickies ... whatever. It's how you feel. Like, I am 30 years old, I'm still wearing Dickies. I'm still wearing the jacket representing [Asian Boyz], but I'm not part of it anymore.

Due largely to their dress and style, P-Dog and his homeboys are frequently "hit up" (harassed) by other gang members and the local police departments. As he explains:

They [the police] ... they check, "What hood are you from? ... What does this number stands for on your body?" They asked for all this stuff, you know. Back when we were young, they asked for cigarette burns ... like, "Why do you have the cigarette burns here?"... you know ... this and that. That's how they represent themselves as Asian gangs, fuck ... in '90, '91.

P-Dog further explains:

The first thing [the police] ask you, "Who do you roll with?" They don't ask, "What's your name?" [I'll say] "I don't roll with nobody." ... They decide to check (for tattoos)... "What does this stand for?" Does it really matter, you know? Back then, I used to tell them where I was from and whatever ... this and that. But [as] I see it now, it shouldn't matter where I am from. You know, we got fucked by cops back in the day when they make the Asian [Gang] Task Force. Asian Task Force used to come and beat our ass up.

P-Dog received his education on the streets. He is a high school drop-out with a 9th grade education. He has gotten straight F's on his report card since the 3rd grade. He was in and out of Los Angeles County's youth detention facilities during his teen years and got most of his high school credits while in juvenile hall. For P-Dog, school was where he went for fun and "to meet girls and get into fights." The junior and high schools P-Dog attended in the Rosemead/San Gabriel area are predominantly Asian and Latino. At his public high school in San Gabriel, his gang would get into fights with other Asian and Chicano/Mexican American gangs.

P-Dog discusses these "race fights" between Asian and Latino students and how these youth experience schooling at his high school and in the West San Gabriel Valley area. He states, "You take any two groups ... they can be best of friends ... stuck in the hall ... stuck in a room for a whole day, they're going to start bugging each other." These "race fights" between racialized groups are by no means just gang members. The general populations at the school would also get involved: 
Just random people ... I don't know how it starts, man. I just know it starts. One day, we say "fuck the ese ... fuck the beaner ... and they would say fuck the chino, you know. That's how it is. We'll get into it and don't know why, to tell you the truth. People will be bringing guns to school. I see that shit all the time ... back when we were going to school.

To get away from gang life in Southern California, P-Dog moved to Seattle to live with an uncle in 1993 when he was 16. He talks about his high school experience in Seattle:

I tripped out in school over there, man. It was like 'Saved by the Bell' [TV show] or something. It's like the show with big-ass lockers. My high school in Seattle's cool. It was good experience, man. I saw, how you say ... the football field is made out of [artificial] turf, you know what I'm saying. It's pretty rich man. It's nice.

He compares his high school in Seattle with the one in Southern California: "You went to the restroom, you see mirrors. San Gabriel [High School] and stuff.... you don't see mirrors, man. They got no lockers for us, man ... like fucking six inches big, six inches wide, you know. It's crazy." P-Dog struggled with traditional schooling and never enjoyed being in the classroom:

[I] never did school ... I didn't like school. I guess I wasn't the kind of person that can sit down and just sit there, you know. It can be trade school. I tried all that trade school. I tried any kind of school that will work for me, that benefit [me] ... not just to learn from the books, but to make a career out there. I'm not saying I'm stupid. I just can't sit in a classroom.

He sums it up: "I just can't do school. Like when I went to continuation [high school], all I got to do is cheat off the notebooks to get a diploma, I couldn't even do that."

The shuttling between different high schools, youth camps, juvenile hall, and continuation school added to P-Dog's instable schooling experiences. He states:

Ever since I turned 16, I'll go to Century [continuation school] until I do good and then go back to regular school. I'll go back to the regular school for a month or two until they kicked me out for getting in a fight. This is at San Gabriel [High School] ... Rosemead [High School]. I went to Rosemead my first year ... got kicked out that place in two weeks. The longest I stayed in school was like, four months.

P-Dog was afforded some stability in Seattle when he stayed at his high school for a full year. Although out of state and away from his homeboys, he could not stay away from trouble: "I was busted for stealing cars and radio. I moved away from the environment that you see in Southern California ... just couldn't get away [from] it." He eventually finished off the school year and went back to California. His one year away from California could have saved P-Dog's life. It was at a time when many of his homeboys went to prison for "putting in work" on rival gangs and were involved in other illicit activities. P-Dog states,

Like I said, a group of 10 friends ... like the 10 I kicked it with, like seven of them are doing life, two of them are dead. I basically lost them all of them at the age of 17 . We're just like 17 years old at the time. We weren't that old. 
P-Dog is a two-strike felon. He was released from prison two months ago at the time of this interview. He is doing a work release program at the Sheriff's headquarters in East Los Angeles to gain his freedom. He has three more months of work before he goes on probation. If P-Dog violates his probation, he will be sent to state prison for three years because of a joint suspension: "I'm straight ... I ain't trying to go up-state [state penitentiary]." Due to his criminal records, P-Dog is not qualified for U.S. naturalization. He is greatly concerned that he might get deported back to Vietnam, a country he has never been to since leaving as a three year old. The deportation issue hits very close to home for P-Dog because he has a friend [due to his criminal records] who recently was deported to Hong Kong. P-Dog is very well aware that Vietnam and the U.S. are making efforts to make this a reality.

\section{Discussion}

P-Dog's narrative tells the story of one gang member who has been socialized in a particular time and place. However, I believe his narrative substantiates how racism in schools and on the streets works together to impact and inform gang formation. The confluence of these two entities are tied to the fact that schools, as institutions of learning (and socialization), are part of the larger state apparatus. Schools, in essence, are an extension of the streets. We can also argue that the streets are an extension of schools. The following sections provide contexts and specificities for P-Dog, his homeboys, and the Asian American youth gang phenomenon in Southern California, especially in the San Gabriel Valley in the late 1980s and early 1990s. Their stories are part of a larger narrative that has impacted youth, but especially youth of color-marked by surveillance, criminalization, and dehumanization.

\section{Racism in the Schools}

Gang formation and schooling are intimately linked in the narrative of P-Dog. His schooling experiences are informed by class, gender, and spatial differences, which are crucial factors in their gang involvement. A significant reason why P-Dog and his friends came together as a gang is because they got tired of being bullied by older Chicano/Mexican American gang members. He tells of incidents of where Lomas (an old local Mexican American gang based in the Rosemead/South San Gabriel/Monterey Park area) gang members were trying to steal his bicycle and pushed him and friends around while they were playing basketball at the park or walking home from their junior high school. They got "hit up" and asked if they belonged to a gang.

In addition to being in conflict with Chicano youth, P-Dog's Asian Boyz gang also had to contend with rival Asian American youth groups in school and the surrounding areas. During the 1980 s and 1990s, these "race fights," or rather, racialized conflicts, were common occurrences at various schools in Southern California. These conflicts are still happening in some Southern Californian schools given dramatic demographic and economic changes and shifting class relations in some areas (Darder \& Torres, 2004). Some of these incidents involving Asian and Latino students occurred in Long Beach (Haldane, 1991); Los Angeles's Lincoln Heights (Quintanilla, 1995), Orange County's Little Saigon area (Gomez \& Boucher, 1991; Rivera \& Licthblau, 1991; Welborn, 2006), and the San Gabriel Valley (Hamilton, 1993; Tawa, 1993).

Over the years, these "race fights" between Asian and Latino students, at varying degrees, occurred at all three high schools (Mark Keppel, San Gabriel, and Alhambra) in the district. Gang members are involved, but by no means are they the only ones. One of the more 
memorable "race fights" occurred in February of 1992 when Asian and Latino students were in conflict with each other at Mark Keppel High School in Alhambra in the West San Gabriel Valley. The tension "boiled over" in two days of fistfights as five Asian and seven Latino students were arrested (Hamilton, 1993). The school was in lock-down, as students were not allowed to leave their classrooms. The police confiscated seven knives, a piece of sharpened glass, and a loaded gun. School officials expelled 24 students and recommended that those arrested be prosecuted for hate crimes.

The 1992 conflict at Keppel High School and other incidents in racialized contexts was a sign of things to come for Vietnamese/Asian American youth in the Los Angeles area. The year P-Dog was sent to live with an uncle out of state, a number of his homeboys got locked upmany of who are doing double life sentences with no parole for murder. Luis Rodriguez, author of Always Running, La Vida Loca: Gang Days in L.A. (1993), and former Lomas member from South San Gabriel, talks about racialized tension between Chicano/Mexican American and white students when he was a Mark Keppel student in the 1970s. In the early 1980s, tensions were brewing between U.S.-born and newly-arrived refugee and immigrant students. Racialized conflict and gang violence went to another level in the 1990s, as it coincides with the accessibility to high-powered firearms.

\section{Racism on the Streets}

In conjunction with their experiences of racism in schools, P-Dog and his homeboys had to deal with racism and discriminatory acts by the local police department. According to P-Dog, their relationship with the police and the Asian Gang Task Force (as alluded to in his narrative), in particular, was always contentious. Invariably, the first thing the police asked them was, "Who do you roll with?" and then proceeded to ask them to lift up their shirts to check for tattoos and cigarette burns, signifiers of Asian gang affiliations back in the day. Given the rise of Asian American youth gangs in Southern California since the 1980s, some police departments created ethnic-specific task forces. The Asian Gang Task Force was set up in multiple locations with visible Asian American gang culture, from Los Angeles to Long Beach, down to Orange County, and back to both valleys (San Gabriel and San Fernando) (Lam, 2009).

In 1987, the Law Enforcement Communication Network and the Los Angeles County Sheriff's Department began to develop a large database known as the Gang Reporting, Evaluation, and Tracking System (GREAT) to "collect, store, and analyze personal information about suspected gang members" (Pintado-Vertner \& Chang, 2000). Also known as Cal-Gang, the database contained more than 300,000 names and was used across the country (p. 10). Since Asian American youth gangs are highly mobile and have satellite groups in other parts of the U.S., this form of surveillance did impact them tremendously. As Pintado-Vertner and Chang (2000) state, these databases "indiscriminately" criminalize youth and identify them as suspects before any crime has been committed (p. 10). It is unfathomable to think that wearing FUBU jeans and being related to a gang member qualifies someone as a "gang member" in some states.

As Daniel Tsang $(1993,1994)$ and Chorswang Ngin (1996) document in their work with Vietnamese American students in Orange County, CA many of these youth unwillingly had their photos taken and are linked to gangs. Ngin (1996) articulates in her ethnographic findings that "Asian youths are racialized through a process of signification based on their fashion and who they 'hang out' with" (p. 93). She further notes that "labels such as 'gang members' and 'gang associate' and signifiers such as hair styles and clothes have become the new 'community' 
criteria for defining gang membership" (p. 93). A number of Vietnamese/Asian youth have been criminalized through this racializing mechanism, as their mugs and files are in the local police departments' gang database.

P-Dog talks about the criminalization of gang members in the 1990s in the contexts of anti-youth legislation which included the Street Terrorism Enforcement and Prevention (STEP) Act of 1988 and Proposition 184, also known as the "three strikes" law. Under the STEP Act, gang membership is punishable up to three years (Gilmore, 2007). So in addition to doing time for the offense, gang members do extra time for violent offense. The STEP Act allows for law enforcement to come up with a set of criteria to determine who is and is not a "gang member." PDog was very aware of laws created to criminalize his status as a "gang member" and his Asian Boyz gang, in particular: "It's not that easy. You get labeled. You're from Asian Boyz, you get labeled, man ... Back then, Pete Wilson (then governor of California) put the 18th Street (large Latino youth gang in Los Angeles) law for the Mexicans ... they put the Asian Boyz law for us." Here, P-Dog is referring to gang injunction placed on so-called high-profile gangs in California, including 18th Street and his own gang. This includes getting extra time because of one's association with the Asian Boyz.

\section{Conclusion}

Second-generation Vietnamese American gang formation does not happen in the vacuum of California/U.S. contemporary urban life. Their "lessons of racism" in schools and the streets are in the context of economic and political turmoil both here in the U.S. and abroad. As migration from Vietnam, Cambodia, and Laos reached its peak in the late 1970s and early 1980s (a consequence of the conflict in Southeast Asia), many of the youth who migrated to the U.S. under these horrendous conditions came of age in the early 1990s. Many started high school after arriving to the U.S. as toddlers. Even though immigration has subsided from Southeast Asia, we see and feel the lasting effects of war and displacement. We see this in the experiences of Vietnamese American youth who negotiated spaces in schools and communities.

This is most evident through P-Dog's narrative. His testimony suggests a number of concerns related to the education of refugee and immigrant populations. His failure, or more specifically, his unwillingness to engage school, tells us that there is a disconnect between schooling and our most marginalized populations. It is clear from his narrative that the schools and streets are highly contentious and dangerous spaces. Students live with real and imagined violence on a daily basis. Like a number of youth of color, especially the most marginalized, there are plenty of Vietnamese/Southeast/Asian American youth who fall through the cracks. In P-Dog's case, he described being disengaged from school at a very young age and never quite recovered from it. He had a very difficult time learning in traditional ways and spaces.

The fact that he was on the move did not afford him much stability. He was constantly on the run. Not surprisingly, he was "in deep" with gang involvement and was not able to get out, both socially and academically. As he mentioned, all he had to do was to copy some work from a notebook to get his high school diploma via continuation school, and he did not even want to do that. In order to be culturally and politically relevant for youth like P-Dog, critical scholars must situate family and community histories within larger discourses of geo-politics, militarization (both overseas and here at home), and class struggle. Educators interested in social justice and economic democracy must seek to understand histories of marginalized populations 
comparatively - and acknowledge that all students bring a certain set of knowledge to the classroom.

For example, it might be good for students to understand and recognize that racialized tensions in the schools and communities stem from major economic, political, economic, and demographic shifts that impact poor and immigrant communities. They are inextricably tied to police brutality and suppression in various communities of color, U.S. economic imperialism, and geopolitics in their countries of origin. Inter-ethnic tensions between Asian and Latino students, as P-Dog alluded to, are not the exception. For example, we see this happening with Black and Latino youth South Los Angeles, and Armenian and Latino students in the San Fernando Valley, to name a few (Lam, 2009). As P-Dog makes clear, it does not matter that you put the "two best friends" in the same room; things will happen, especially if students do not and have not yet developed a language of critique and solidarity. Perhaps critical pedagogical approaches and an ethnic studies curriculum and classes might be useful at junior high and high schools. Oftentimes, "diversity" and "sensitivity" training is put in place only after racialized conflicts happen at schools and spill out onto the streets - with serious consequences.

This article attempts to fill some of the gaps that currently exist in the literature on Asian American youth and students today, in particular those youth who are involved with gangs. While there is some literature on the racialization (e.g., "ideological blackening") of Southeast Asian American youth (Lee, 2005, 2009; Ong, 2003; Reyes, 2007), it is my intent to build on this literature by examining how Vietnamese American youth gang members experience schooling and its relationship to racism, class, and migration. The material implications are real, as reflected through P-Dog's narrative and should have an impact on our theorizing and policymaking. Hence, we cannot begin to talk about educational policy issues and their impact on Vietnamese American youth without understanding the differences and complexities of the historical, political, and economic trajectories that shape the lives and academic experiences of youth from Vietnamese and Asian American communities.

\section{Note}

The author thanks Jennifer Y. Chung for her critical feedback, invaluable editorial support, and general encouragement for this article.

\section{References}

Asian Gangs in Los Angeles County (2012). Asian gangs. Retrieved from http://www.streetgangs.com/asian

Chan, S. (1994). Asian Americans: An interpretive history. New York: Twayne Publishers.

Chow, G. K. (2005). Exiled once again: Consequences of the congressional expansion of deportable offenses on Southeast Asian refugee community. Asian Law Journal, 12, 103136.

Darder, A., \& Torres, R. (2004). After race: Racism after multiculturalism. New York: New York University Press.

Espiritu, Y. L. (2005). Thirty years afterWARd: The endings that are not over. Amerasia Journal, 31(2), xiii-xxiii.

Espiritu, Y. L. (2006). The 'we-win-even-when-we-lose' syndrome: U.S. press coverage of the twenty-fifth anniversary of the 'Fall of Saigon.' American Quarterly, 58(2), 329-352. 
Fanon, F. (1963). The wretched of the earth. New York: Grove Press.

Freire, P. (1970/1993). Pedagogy of the Oppressed. New York: Continuum.

Gilmore, R. W. (2007). Golden gulag: Prisons, surplus, crisis, and opposition in globalizing California. Berkeley, CA: University of California Press.

Gomez, J., \& Boucher, G. (1991, September 30). Latinos beat 3 Asian students. Los Angeles Times, p. 1.

Gonzales, R. (2004, September 26). Asian gangs latest threat sweeping the neighborhood. Pasadena Star-News, p. 1.

Guerra Vasquez, G. A. (2005). Homies unidos: International barrio warriors waging peace on two fronts. In S. Maira \& E. Soep (Eds.), Youthscapes: The popular, the national, and the global (pp. 103-118). Philadelphia: University of Pennsylvania Press.

Haldane, D. (1991, April 15). Latino and Asian gangs engage in deadly warfare violence. Los Angeles Times, p. 1.

Hamilton, D. (1993, June 10), Tension between Asian and Latino students in the Alhambra school district has climbed to a fever pitch. Los Angeles Times, p. 1.

Hune, S. (2002). Demographics and diversity of Asian American college students. In M. K. McEwen, C. M. Kodama, A. N. Alvarez, S. Lee, \& C. T. H. Liang (Eds.), Working with Asian American college students: New directions for student services (pp. 11-20). San Francisco, CA: Jossey-Bass.

Kwon, S. (2006). Youth of color organizing for juvenile justice. In S. Ginwright, P. Noguera, \& J. Cammarota (Eds.), Beyond resistance!: Youth activism and community change (pp. 215-228). New York: Routledge.

Lam, K. (2009). Reppin' 4 life: The formation and racialization of Vietnamese American youth gangs in Southern California (Unpublished doctoral dissertation). University of Illinois, Urbana Champaign, Illinois.

Le, T. (2002). Delinquency among Asian/Pacific Islanders: Review of literature and research. Justice Professional, 15(1), 57-70.

Lee, S. (2005). Up against whiteness: Race, school and immigrant youth. New York: Teachers College Press.

Lee, S. (2009). Unraveling the model minority stereotype: Listening to Asian American youth. New York: Teachers College Press.

Madison, D. S. (2005). Critical ethnography, method, ethics, and performance. Thousand Oaks, CA: Sage.

Nayak, A. (2003). Race, place and globalization: Youth cultures in a changing world. Oxford, England: Berg.

Ngin, C. (1996). Racism and racialized discourse on the Asian Youth in Orange County. Retrieved from http://www.patbrowninstitute.org/documents/RacismandRacializedDiscourseonAsianYou thinOrangeCounty.pdf

Ong, A. (2003). Buddha is hiding: Refugees, citizenship, the new America. Berkeley, CA: University of California Press.

Osajima, K. (2000). Asian Americans as the model minority: An analysis of the popular press image in the 1960s and 1980s. In M. Zhou \& J. Gatewood (Eds.), Contemporary Asian America: A multidisciplinary reader (pp. 449-458). New York: New York University Press.

Pintado-Vertner, R., \& Chang, J. (2000). The war on youth. Colorlines, 2(4), 9-15. 
Quintanilla, M. (1995, September 29). Children of hope. Los Angeles Times, p. 1.

Reyes, A. (2007). Language, identity, and stereotype among Southeast Asian American youth: The other Asian. Mahwah, NJ: Lawrence Erlbaum.

Rivera, C., \& Licthblau, E. (1991, September 19). After-school fight blamed on ethnic tension unrest: A Westminster high student was knifed when Latino and Asian youngsters scuffled near the campus. Los Angeles Times, p. 1.

Rodriguez, L. (1993). Always running, la vida loca: Gang days in L.A. New York: Simon \& Schuster.

Takaki, R. (1989). Strangers from a different shore. New York: William Morrow.

Tawa, R. (1993, December 05). Students learn about bias - their own: Race relations: Hoping to unmask stereotypes, Pitzer College students present eye-opening workshops at three local high schools. Los Angeles Times, p. 1.

Tsang, D. (1993). Is innocent until proven guilty a lost principle? Retrieved from https://webfiles.uci.edu/dtsang/public/lostprin.htm

Tsang, D. (1994). Asians are automatically labeled gang members. Retrieved from https://webfiles.uci.edu/dtsang/public/asiansgang.html

Umemoto, K., \& Ong, P. (2006). Asian American and Pacific Islander youth: Risks, challenges, and opportunities. APPI Nexus, 4(2), v-ix.

Vigil, J. D. (2002). Rainbow of gangs: Street cultures in the mega-city. Austin, TX: University of Texas Press.

Vigil, J. D., Nguyen, T.H., \& Cheng, J. (2006). Asian Americans on the Streets: Strategies for Prevention and Intervention," APPI Nexus, 4(2), pp. 1-11.

Vigil, J. D., \& Yun, S. C. (1998). Vietnamese youth gangs in the context of multiple marginality and the Los Angeles youth gang phenomenon. In K. Hazelhurst \& C. Hazelhurst (Eds.), Gangs and youth subcultures: International explorations (pp. 117-139). New Brunswick, NJ: Transaction Publishers.

Welborn, L. (2006, May 10). 2 reputed gang members convicted of murdering boy, 14. Orange County Register, p.1.

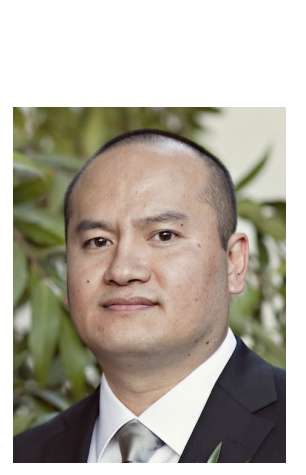

\section{About the Author}

Kevin D. Lam is an Assistant Professor of Urban and Diversity Education in the Department of Teaching \& Learning at Drake University (Des Moines, IA). Kevin was born in Vietnam and raised in Los Angeles. He received his B.A. degree in Sociology with a specialization in Asian American Studies at UCLA, M.A. in Educational Foundations from CSU-Los Angeles, and Ph.D. in Educational Policy Studies from the University of Illinois, UrbanaChampaign. Prior to pursuing graduate studies, he worked as a K-12 teacher and gang prevention youth worker in the Los Angeles area for six years. His research and teaching interests include Asian American youth gangs, critical theories of racism, critical pedagogy, urban education, and political economy. 


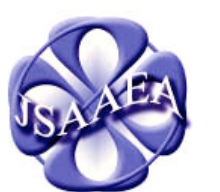

Volume 7 (2012)

\section{Journal of Southeast Asian American Education \& Advancement}

\author{
WwW.JSAAEA.org
}

\section{Editor}

Dr. Wayne E. Wright

University of Texas, San Antonio

\author{
Associate Editors \\ Dr. Chhany Sak-Humphry \\ University of Hawaii at Manoa
}

Dr. Phitsamay Sychitkokhong Uy

University of Massachusetts, Lowell

\section{Book Review Editor}

Dr. Vichet Chhuon

University of Minnesota

\section{Creative Works Editor \\ Bryan Thao Worra \\ Lao Assistance Center}

Special Advisor

Gregory Green

Curator, Echols Collection on Southeast Asia, Cornell University Library

\author{
Journal Manager \\ Sovicheth Boun \\ University of Texas, San Antonio
}

A peer-reviewed scholarly journal published by the

National Association for the Education \& Advancement of Cambodian, Laotian, and Vietnamese Americans (NAFEA)

Comments and questions for the editorial staff may be directed to jsaaea@lists.sis.utsa.edu

\section{Editorial Review Board}

\author{
Dr. Steve Arounsack \\ California State University, Stanislaus \\ Dr. Phala Chea \\ Lowell Public Schools \\ Dr. Loan Dao \\ University of Massachusetts, Boston \\ Dr. Changming Duan \\ University of Missouri, Kansas City \\ Dr. Jeremy Hein \\ University of Wisconsin - Eau Claire \\ Dr. Samlong Inthaly \\ Minneapolis Public Schools \\ Dr. Kevin K. Kumashiro \\ University of Illinois, Chicago
}

\author{
Dr. Carl L. Bankston III \\ Tulane University \\ Dr. George Chigas \\ University of Massachusetts, Lowell \\ Dr. Hien Duc Do \\ San Jose State University \\ Dr. Sophal Ear \\ U.S. Naval Postgraduate School \\ Dr. Nancy H. Hornberger \\ University of Pennsylvania \\ Dr. Peter Nien-Chu Kiang \\ University of Massachusetts, Boston \\ Dr. Ha Lam \\ Arizona State University
}



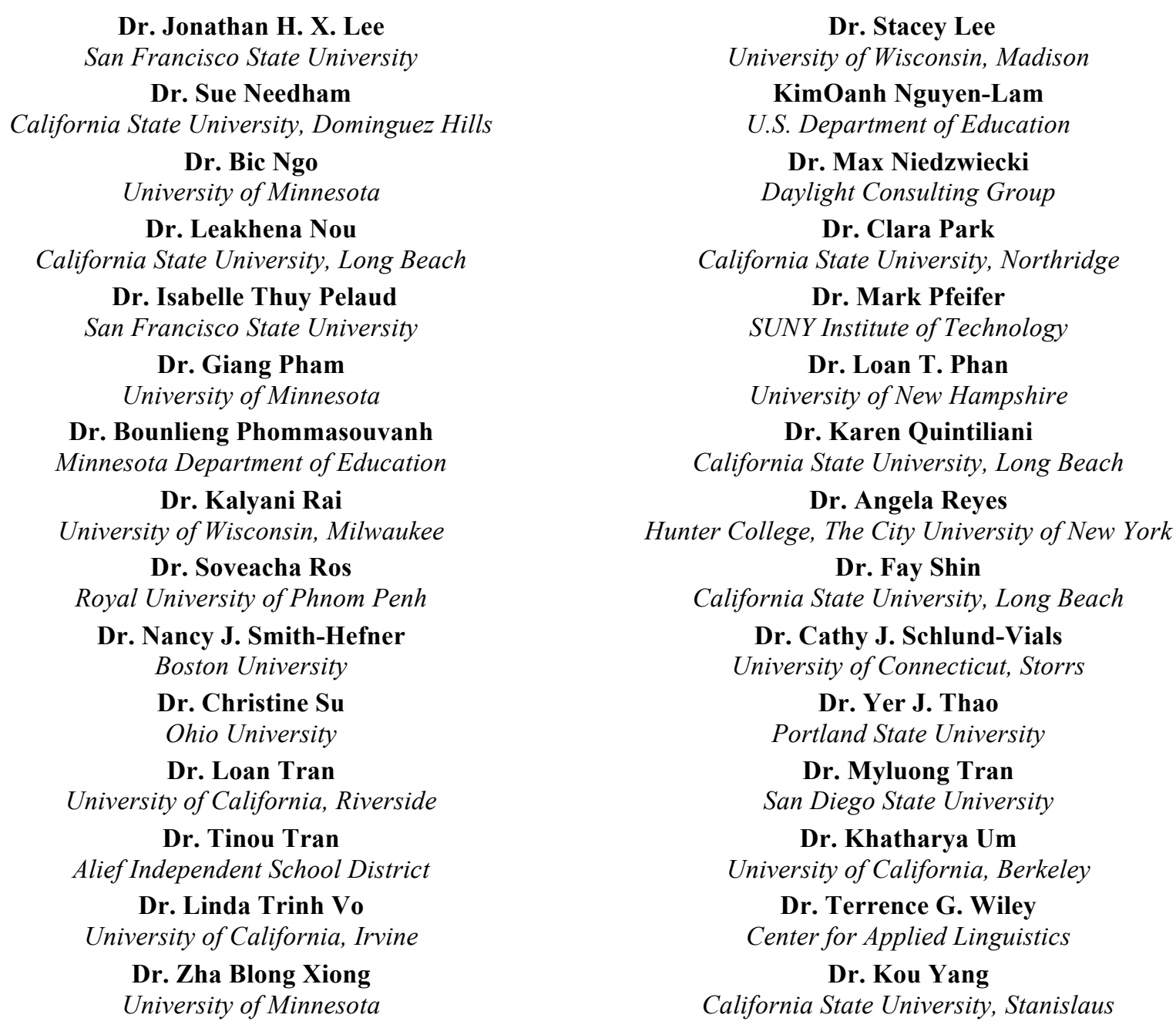

\section{Doctoral Student Editorial Review Board}

\author{
Keo Chea-Young \\ University of Pennsylvania \\ Ketmani Kouanchao \\ California State University, Fullerton \\ Ravy Lao \\ University of California, Santa Barbara \\ Thien-Huong Ninh \\ University of Southern California \\ Vanna Som \\ Harvard University \\ Krissyvan Truong \\ Claremount Graduate University \\ Yang Sao Xiong \\ University of California, Los Angeles
}

\author{
Annie BichLoan Duong \\ San Joaquin County Office of Education \\ Peter Tan Keo \\ Columbia University \\ Monirith Ly \\ Texas State University-San Marcos \\ Malaphone Phommasa \\ University of California, Santa Barbara \\ Alisia Tran \\ University of Minnesota \\ Silvy Un \\ University of Minnesota \\ Yeng Yang \\ University of Texas, San Antonio
}

